\title{
Energy Conservation and Solar Energy Use for Cooking - Impact of Its Massive Adoption in the Arid Zone of Argentina
}

\author{
Alfredo Esteves ${ }^{1,2, *}$, Carolina Ganem ${ }^{1}$ and M. Victoria Mercado ${ }^{1}$ \\ ${ }^{1}$ INCIHUSA, CCT Mendoza CONICET C.C. 131, 5500 Mendoza, Argentina \\ 2 DICYTV, University of Mendoza, Arístides Villanueva 773, 5500 Mendoza, Argentina
}

\begin{abstract}
The use of solar energy is essential in transforming today's human environments into tomorrow's sustainable human habitats. This paper presents the positive impacts produced by the adoption of energyefficient cooking equipment - using heat retention box cookers and the solar drum ovens - in the arid zone of Argentina. These solar cooking technologies improve the quality of life for local populations and, at the same time, save energy, time and effort in trying to obtain firewood. They minimize serious health problems associated with greenhouse gas (GHG) emissions control. The study documented in this paper demonstrates that usage of these technologies results in the saving of $65.7 \%$ of Liquefied Petroleum Gas (LPG) and $63.8 \%$ of Firewood (FW) utilized in Argentina's rural and arid zone. These results indicate that, if $50 \%$ of the arid zone population were to adopt these technologies, a reduction of $3.09 \mathrm{~kg} \mathrm{CO}_{2}$ of greenhouse gases per capita from 2015 to 2050 is possible.
\end{abstract}

Keywords: Energy- efficient cooking, solar cooking, energy situation of arid zones

DOI: http://dx.doi.org/10.7492/IJAEC.2014.004

\section{INTRODUCTION}

A report by the Intergovernmental Panel on Climate Change (IPCC 2011) mentioned that $80 \%$ of the world's energy needs could be covered by renewable sources by 2050, if public policies are established to this end. Such an eventuality would allow for the saving of greenhouse gases on the order of 220 to 560 Gigatons of carbon dioxide equivalent between 2010 and 2050. Key relevant mitigation measures include: energy conservation, renewable energy, passive solar heating, passive cooling, natural lighting, energy efficient equipment, etc.

Lifestyle practices have a clear impact on energy usage and pollution; in a situation of prosperity there is more consumption. Increased prosperity leads to the increased use of resources, greater waste generation, and growing emissions of $\mathrm{CO}_{2}$.

The use of both solar energy and energy conservation practices, especially in those places where sunlight is abundant, can contribute to the reduction of green- house gas (GHG) emissions. For example, looking at global consumption, if energy efficiency is practiced, it is possible to save $43 \%$ of the consumption of primary energy. $18 \%$ of these savings are in the residential sector, $10 \%$ in the industrial sector, and $17 \%$ in transport (Mandil 2007). In the same vein, the President of the IEA, emphasizes that the use of alternative energies encourages sustainable economic development, indicating at the same time the need for further development of renewable energy.

In the case of Argentina, Volantino and Cornejo (2005) indicates a threshold of the expected savings if conservation and energy efficiency mechanisms are adopted in the residential sector. This research indicates savings of $43 \%$, taking into account the insulation of walls and roofs, and this value could reach $50 \%$ if double glazing is used.

$86.9 \%$ of the consumption of Argentina's primary energy is supplied by oil and natural gas (Ministerio de Economía 2012) (see Figure 1(a)). The rest is distributed with $4.3 \%$ hydro-energy, $2.7 \%$ nuclear, and

\footnotetext{
*Corresponding author. Email: alfredo.esteves@um.edu.ar
} 


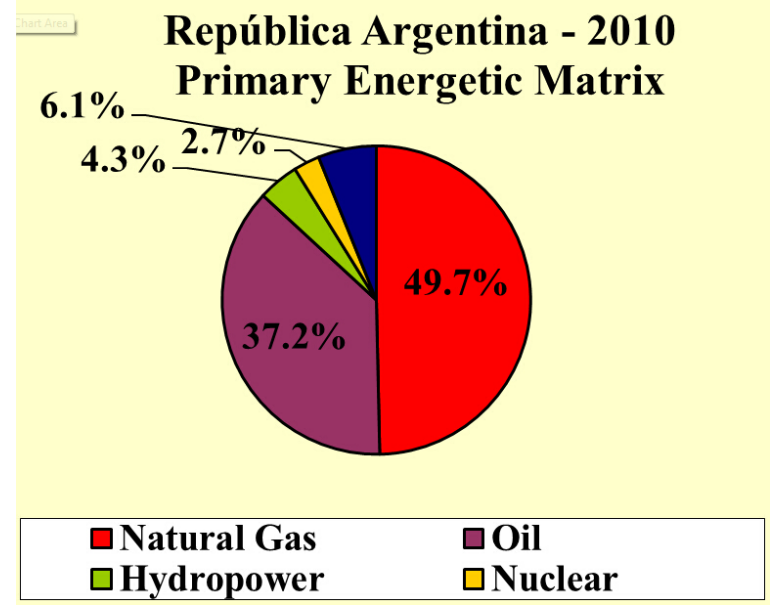

(a)

\author{
República Argentina \\ Primary Energy Consumption \\ 76778 thous ands of TOE
}
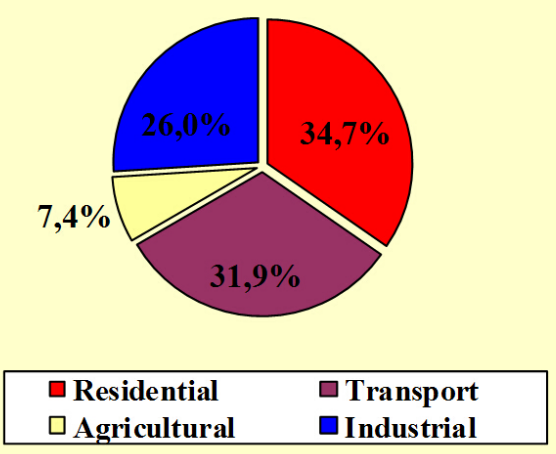

(b)

Figure 1. From left to right: energetic matrix and primary energy consumption in Argentina 2010

$6.1 \%$ others (firewood, bagasse, etc.). This consumption is partitioned with average values of $34.7 \%$ in the residential sector, $31.9 \%$ in the transport sector, $26 \%$ in the industrial sector and $7 \%$ in the agricultural sector (Figure 1(b)). From residential sector, the energy consumption for cooking is approximately $2 \%$.

The economic cost of fuels depends on the location of buildings. Those in urban areas consume natural gas for heating, cooking, and water heating at a cost of USD $0.008 / \mathrm{kWh}$ (date $02 / 2013$ ); and power for electrical equipment (TV, communication equipment and other devices) with a cost of USD $0.06 / \mathrm{kWh}$. In rural isolated areas, Liquefied Gas of Petroleum (LPG) and Firewood (FW) are used. Approximately 2.3 million people in almost 466,000 homes and 7,000 public buildings (schools, health centre, police detachments, etc.) are located in these areas. The cost of energy is USD $0.088 / \mathrm{kWh}$ for LPG and USD $0.0624 / \mathrm{kWh}$ for FW. It is important to see that in isolated zones, the cost of gas is 11 times more expensive than in urban zones.
In the majority of rural isolated communities there are health centres and schools. The majority of the population consists of goat shepherds, but some people are self-employed or civil servants; there are some unemployed people too. In these communities, there are a few basic social needs that are lacking. These include an increased availability of water, public telephones, public squares with children's games, and better public transportation with reasonable frequency (Esteves et al. 1999).

Surveys were used to diagnose the energy needs of a sample set of families in the arid zone. The data in Table 1 was taken from Mitchell and Esteves (2004) and Quiroga et al. (2010). The reader should note that the energy sources used are symbolized as firewood (FW), liquefied gas (LPG), electrical energy (EE) and kerosene (KE):

Inhabitants of the rural arid zone devote massive amounts of time and effort in trying to obtain firewood. As a consequence, they suffer from related health problems, including injuries, tears, suffocation due to smoke

Table 1. Situation of families in arid zones of Argentina

\begin{tabular}{|c|c|c|c|c|}
\hline Item & LPG use & FW use & EE use & Observations \\
\hline Energy consumption per month & $10.1 \mathrm{~kg}$ of LPG & $100 \mathrm{~kg}$ of $\mathrm{FW}\left(^{*}\right)$ & & \\
\hline \multirow[t]{2}{*}{ For cooking } & $\begin{array}{l}30 \% \text { only have a } \\
\text { LPG oven }\end{array}$ & $\begin{array}{l}21 \% \text { only have a } \\
\text { FW oven }\end{array}$ & & $\begin{array}{l}\% \text { do not have } \\
\text { any oven }\end{array}$ \\
\hline & $43 \%$ have LPG and & FW ovens & & \\
\hline For Sanitary water heating $(* *)$ & $\begin{array}{l}6 \% \text { have a LPG } \\
\text { heater }\end{array}$ & $\begin{array}{l}85 \% \text { have a } \mathrm{FW} \\
\text { heater }\end{array}$ & $\begin{array}{l}6 \% \text { have an } \mathrm{EE} \\
\text { heater }\end{array}$ & \\
\hline For building heating & $\begin{array}{l}2 \% \text { have a } \mathrm{LPG} \\
\text { air heater }\end{array}$ & $\begin{array}{l}83 \% \text { use a } \mathrm{FW} \mathrm{s-} \\
\text { tove }\end{array}$ & $\begin{array}{l}11 \% \text { have an } \mathrm{EE} \\
\text { heater }\end{array}$ & $\begin{array}{l}4 \% \text { does not heat } \\
\text { the building }\end{array}$ \\
\hline For building cooling & \multicolumn{4}{|c|}{ Energy is not used to cool houses, but they are built with high thermal mass } \\
\hline Time spent in cooking & $2.2 \mathrm{hrs}$ for lunch & $1.7 \mathrm{hrs}$ for dinner & $\begin{array}{l}<1 \mathrm{hr} \text { for break- } \\
\text { fast }\end{array}$ & $\begin{array}{l}<1 \mathrm{~h} \text { to prepare } \\
\text { mate }^{* * *}\end{array}$ \\
\hline
\end{tabular}

Note: * - When people use only $\mathrm{FW}$ the monthly consumption is $500 \mathrm{~kg}$

$* *-61.1 \%$ prefer natural gas-GN because it is clean, cheap and comfortable

*** - drink deeply rooted in the south of Latin America being prepared as infusion from the yerba mate 
inhalation, burns, back pains, wounded lacerations, illnesses of the bowels when ingesting water without disinfection, and opportunity costs, i.e., not using their time to pursue other gainful activities. Furthermore, the rampant collection of firewood leads to the gradual destruction of their ecological habitat, accelerating the desertification process. In addition, air pollution is generated due to the constant emission of greenhouse gases.

The Project of Renewable Energy in Scattered Rural Markets (PERMER) is a government program created to supply energy to isolated rural areas outside of the electrical grid using renewable sources. The provision of electricity is through photovoltaic, mini-wind, micro-hydraulic and fuel cells. In this way, PERMER helps to reduce the migration of rural peoples to large urban centres (Cerioni and Morresi 2008). Additionally, it supplies energy for public buildings, e.g., schools, health posts, and police detachments. The PERMER program does not include thermal devices, only electrical equipment.

The implementation of energy conservation practices and solar energy sources is strategic in helping the inhabitants of isolated communities and showing them how to live using their natural resources. For these people the knowledge of solar energy technology is not obvious, as solar energy use and maintenance is not featured in local primary or secondary schools.

In spite of the technological progress that has been made, it is not often easy to implement new technologies in remote areas with scarce resources. In developing countries, poverty is a common denominator with the ubiquitous lack of resources, limited access to technology and knowledge. Researchers are seeking out options for development to meet the basic needs in sustainable ways. There are many development models to assist these rural isolated people, but it is clear that successful interventions must involve them in charting their own course of development (Guzman et al. 1992).

Solar technology seems like a valuable alternative for those rural communities where weather conditions are sufficiently acceptable. An interesting example of solar technology transfer is the Nacuñán experience, a rural isolated community in Central Western Argentina. They have enthusiastically participated in the solution of one of their specific problems: energy supply for cooking. They accepted the solar cooker, and in this way began the process of getting sustainable energy. This represents their first approach towards community sustainable development.

This paper analyzes energy conservation and solar energy use for cooking in rural isolated communities. The energy savings and environmental impact are calculated as a function of the number of houses and climatic characteristics of arid zones of Argentina.

\section{GEOGRAPHICAL CHARACTERISTIC OF ISOLATED COMMUNITIES OF ARID ZONES OF ARGENTINA}

Many of the rural and isolated communities of Argentina are found in arid or semiarid climates. These climates are subdivided into different zones that are called: arid mountain, arid hills, arid steppe and arid Patagonia (Figure 2). These climates are characterized by high temperature fluctuations - low temperatures in winter, high temperatures in summer, low relative humidity and high clearness which allow several sunny and partly cloudy days per year.

In Figure 2, the left map shows the different climatic zones of Argentina: arid, warm humid, warm wet and cold wet. It is possible to see that about half of the country is in arid climates. Zones 2, 3, 4, 5 and 7 are arid zones and are targets for technology transfer of energy conservation and solar systems for cooking. The right side of Figure 2 is a map of annual average daily solar radiation over the horizontal plane.

\section{NUMBER OF DWELLINGS IN THE ARID ZONE}

Table 2 indicates the amount of rural housing in the area. The arid zones are defined as those with less than $300 \mathrm{~mm}$ of annual precipitation (Secretaría de Ambiente y Desarrollo Sustentable 2012).

Taking into account the 2010 Census of population and housing, the number of homes in the country is $13,835,751$ houses (INDEC 2012). $86.9 \%$ of these homes are in urban areas and $13.1 \%$ are found in rural areas. In Figure 1, the provinces which possess arid climates are indicated in different climatic zones. By taking the number of rural houses distributed by province, one can obtain the rural houses to which energy conservation and solar systems for cooking are applicable. These households represent the objective of this work.

\section{CLIMATIC CONDITIONS}

To know the weather conditions of each zone, recorded data of the decade 1990-2000 has been taken into account. These data are registered by the National Weather Service of Argentina - Servicio Meteorológico Nacional (SMN 2004). For the purposes of this work, the meteorological data of Salta is used for arid mountain climates; the meteorological data of Santiago del Estero for dry warm climates; the meteorological data of Mendoza for arid hills climate; the meteorological data of Neuquén for the arid steppe climate; and for the arid Patagonia climate, the meteorological data of Trelew. Table 3 indicates temperatures, solar radiation, number of clear and partially clear days and average wind velocity. 


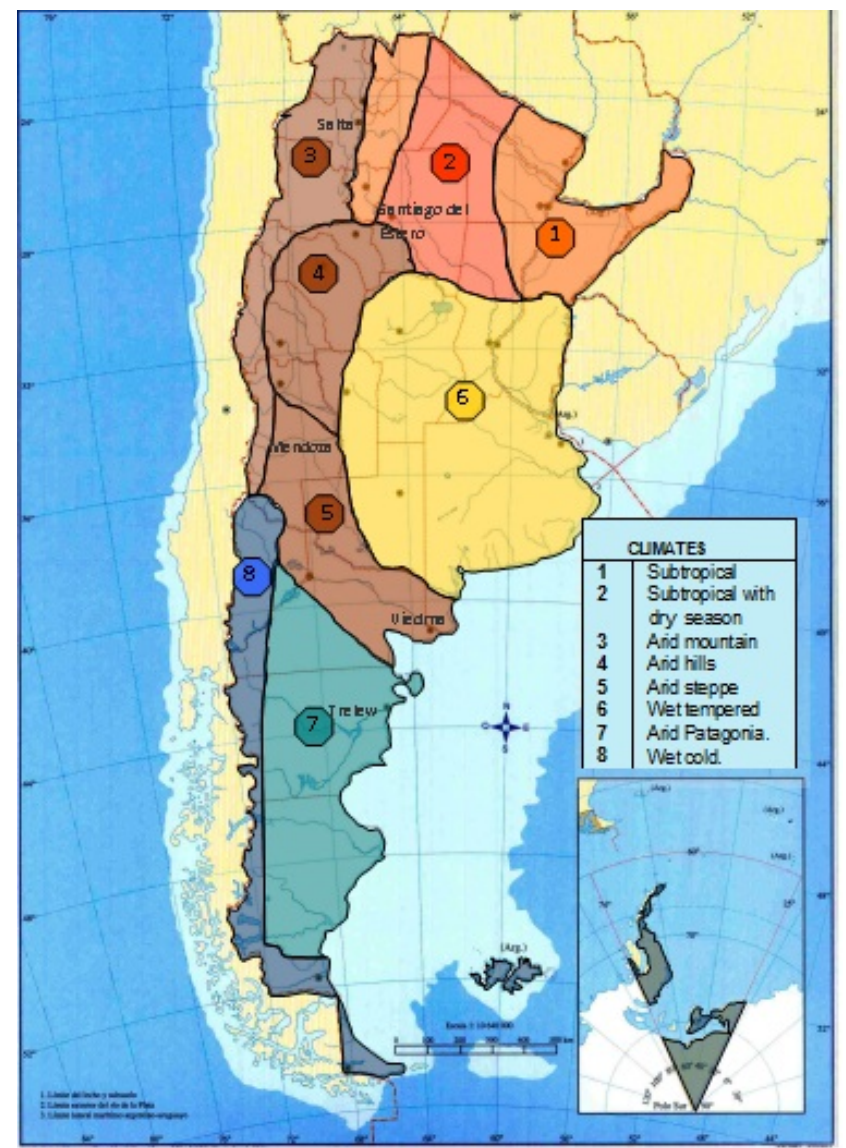

(a)

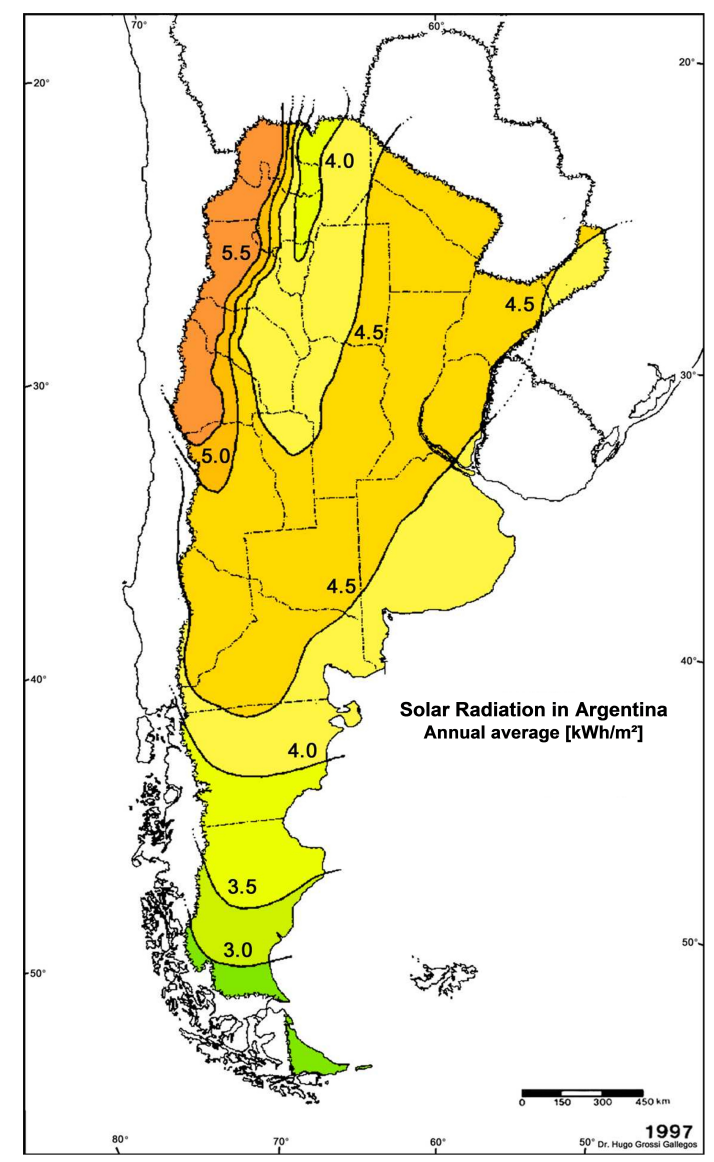

(b)

Figure 2. Maps of Argentina with arid climate zones and solar radiation distribution

\section{TECHNOLOGY DESCRIPTION}

The energy spent in cooking is of supreme importance in rural communities, especially in developing societies. The nutritional value of foods depends on the variety of different food groups, and energy is vital for their preparation.

It is important to remember that the essential nutrients for human development and the maintenance of a balanced metabolism are: proteins, carbohydrates, fats, vitamins, minerals and water. These are normally grouped into 5 categories:

Group 1 milk and derivatives

Group 2 meats and eggs

Group 3 fruits and vegetables

Group 4 cereals and legumes

Group 5 oils, sweets and sugar

From each group it is necessary to ingest one portion

Table 2. Number of houses units in arid region of Argentina

\begin{tabular}{llrrr}
\hline Geographical Zone & Province & Total houses in the zone & Total houses in rural zone & Total houses in arid rural zone \\
\hline Northwestern & Jujuy & 196,286 & 47,477 & 28,486 \\
& Salta & 315,941 & 77,366 & 30,946 \\
& Catamarca & 114,019 & 40,310 & 40,310 \\
Northeastern & Formosa & 154,694 & 49,240 & 34,468 \\
\multirow{3}{*}{ Centralwestern } & Chaco & 312,972 & 50,227 & 35,159 \\
& La Rioja & 109,182 & 29,914 & 29,914 \\
\multirow{2}{*}{ Patagonian north } & Mendoza & 539,271 & 121,575 & 121,575 \\
& San Juan & 188,946 & 38,729 & 38,729 \\
Patagonian South & Reuquén & 194,613 & 29,253 & 14,627 \\
Total & Chubut & 237,387 & 55,568 & 50,011 \\
& & 178,845 & 45,824 & 41,242 \\
\hline
\end{tabular}


Table 3. Climatic conditions in different arid zones of Argentina

\begin{tabular}{|c|c|c|c|c|c|c|c|}
\hline Geographical zones & Climatic zone & $\begin{array}{l}\text { Maximum } \\
\text { ambient } \\
\text { temperature } \\
\left({ }^{\circ} \mathrm{C}\right)\end{array}$ & $\begin{array}{l}\text { Mean } \\
\text { ambient } \\
\text { temperatur } \\
\left({ }^{\circ} \mathrm{C}\right)\end{array}$ & $\begin{array}{l}\text { Solar ra- } \\
\text { diation } \\
\mathrm{e}\left(\mathrm{kWh} / m^{2}\right)\end{array}$ & $\begin{array}{l}\text { Number of } \\
\text { clear days } \\
\text { (unid/yr) }\end{array}$ & $\begin{array}{l}\text { Number of } \\
\text { partially } \\
\text { cloudy } \\
\text { days } \\
\text { (unid/yr) }\end{array}$ & $\begin{array}{l}\text { Wind } \\
\text { velocity } \\
(\mathrm{km} / \mathrm{hr})\end{array}$ \\
\hline Northwestern & Arid Mountain & 27.9 & 14.2 & $5.0-5.5$ & 143.9 & 142.8 & 19.6 \\
\hline Northeastern & Dry warm & 27.2 & 15.4 & $4.0-4.5$ & 120.1 & 142.0 & 112.0 \\
\hline Central western & Arid hills & 24.1 & 17.0 & $4.0-4.5$ & 128.2 & 179.7 & 8.1 \\
\hline Patagonian North & Arid steppe & 21.0 & 13.9 & $4.0-4.5$ & 110.0 & 187.2 & 22.2 \\
\hline Patagonian South & Arid Patagonia & 20.7 & 13.5 & $3.0-4.5$ & 77.6 & 215.6 & 23.0 \\
\hline
\end{tabular}

every day (at least). Poor nutrition and malnutrition produces stunted growth, cognitive impairment and elevated susceptibility to disease.

INCIHUSA (Social and Environmental, Human Science Institute) has developed several pieces of equipment to improve energy efficiency and facilitate solar energy use. These include the heat retention box cooker for family and children dinners (Mercado and Esteves 2004), the solar oven for cooking (Esteves et al. 1999) and for pasteurization (Esteves et al. 2006), as well as passive solar systems for heating and cooling (Ganem 2006; Mercado et al. 2013; Filipin et al. 1998), etc. This paper will focus on the use of the heat retention box cooker and the solar drum oven.

\subsection{Heat Retention Box Cooker Technolo- gy}

One way to conserve energy in food preparation is to cook with a heat retention box cooker (HRBC). This device permits one to minimize the usage of gas or firewood while cooking. Once food is heated to the boiling point, the temperature need not be increased any higher to effectively cook food, meaning energy only needs to be used to maintain the boiling-point temperature. In an HRBC, once food is heated to boiling, cooking continues in an insulated box. Like an oven, the HRBC permits energy conservation. Figure 3 shows images of $\mathrm{HRBC}$ fabricated in Mendoza, Argentina. It is made of an expanded polystyrene box containing 6 pieces with dimensions of $0.30 \mathrm{~m} \times 0.40 \mathrm{~m} \times 0.05 \mathrm{~m}$ each. The interior consists of cardboard with aluminium foil coating in order to generate a radiant barrier. The pot is placed on a wooden base in order to avoid overheating and destroying the expanded polystyrene bottom. The $\mathrm{HRBC}$ is easy to construct, so it can be replicated in a community workshop or by non-skilled personnel.

Figure 4 shows the temperature of the pot when heated to boiling and cooking with and without HRBC. Without HRBC it should be left on gas stove burner to maintain the temperature, which in this case is extended until 50 minutes. The figure also shows the case of cooking in HRBC, in which, after 10 minutes when the pot reaches the boiling temperature, it is put into the HRBC and stays there until the end of the cooking. The time that the pot is in the HRBC is directly proportional to the savings in consumption of LPG or FW.

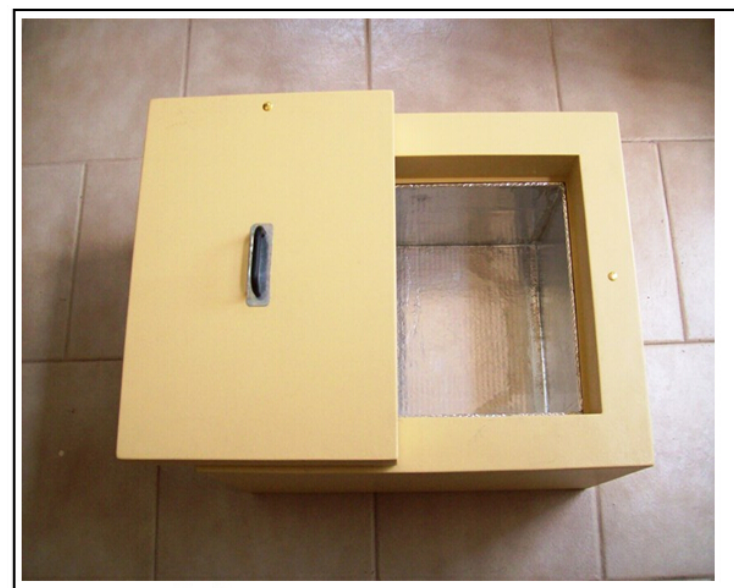

References:

1- Cap of heat retention box.

2- Interior with cardboard and aluminium sheet coating 3- Pot with sweet plum.

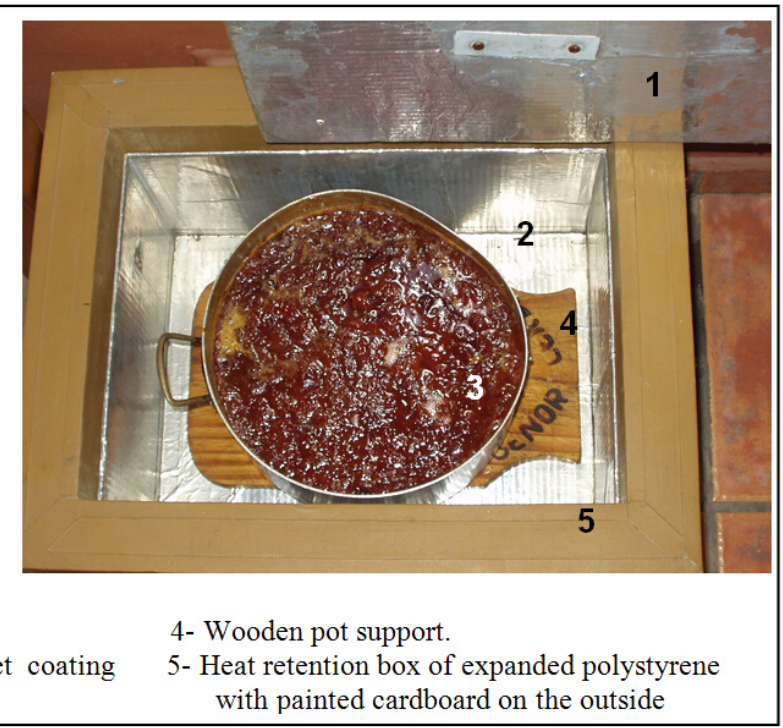

Figure 3. Heat retention box cooker 


\section{Cooking process with and without HRBC} mass of water: $2.3 \mathrm{~kg}$

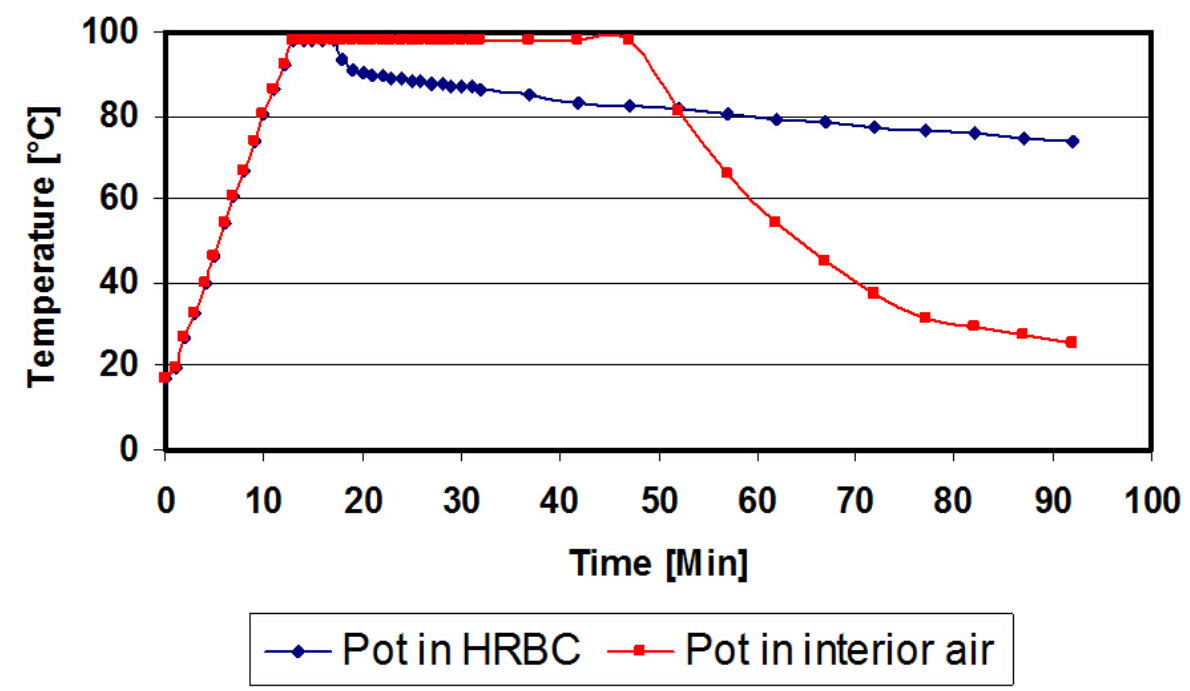

Figure 4. Pot temperature when heating up to boiling and then cooling without and with heat retention box cooker

It is possible to express the heat transfer from pot to ambient by Eq. (1)(Kreith 2001).

$$
\frac{d Q}{d t}=-U \cdot A \cdot\left(T-T_{a}\right)
$$

where $d Q$ is the amount of heat lost in the unit of time; $d t$ is differential of time $[\mathrm{s}] ; U$ is heat transfer coefficient; $A$ is area of heat exchange, perpendicular to the heat flow; $T$ is temperature inside the pot; $T_{a}$ is ambient temperature external to the pot.

As the pot has a certain load of food, the heat $d Q$ delivered by the food, when it cools down according to a $d T$, can be calculated by Eq. (2). As the specific heats of humid foods are very similar to the specific heat of water, it is here assumed that they are equivalent for purposes of these calculations.

$$
d Q=m \cdot \mathrm{d} T=\rho \cdot V \cdot c d T
$$

where $d Q$ is heat losses from the pot in time unit $W$; $m$ is mass of water; $c$ is specific heat of water; $d T$ is differential of temperature of water into the pot; $\rho$ is density of water; and $V$ is volume of water in the pot.

\section{Therefore:}

$$
\rho \cdot V \cdot c \frac{d T}{d t}=-U \cdot A\left(T-T_{a}\right)
$$

The minus sign indicates that the internal energy decreases when $T>T_{a}$. Separating variables and integrating, taking into account, $T_{o}$, is the initial pot temperature and, $T$, is the temperature of the water on time, $t$, and considering, $T_{a}$, constant during the process, Eq. (4) is obtained.

$$
\ln \frac{T-T_{a}}{T_{o}-T_{a}}=-\frac{U \cdot A}{\rho \cdot V \cdot c} t
$$

Then, Eq. (5) is obtained as

$$
T=T_{a}+\left(T_{o}-T_{a}\right) \exp \left(-\frac{U \cdot A}{\rho \cdot V \cdot c} t\right)
$$

It is clear that the resulting temperature depends on the magnitude of $U$. With HRBC the $U$ value is lower than without HRBC, therefore temperature $T$ remains sufficiently high during cooking (in any time $t$ ). Another variable that modifies $T$, is the water volume $V$. The higher the volume $V$, the higher the resulting temperature, $T$, in a given time, $t$. Figure 5 shows the temperature of the water in the pot inside the HRBC for different loads of water, $m$. It can be seen that the temperature is more stable when the load of water is higher.

The equation that governs the testing presented in Figure 5 is indicated in Eq. (6). Taking into account that the boiling temperature is $100{ }^{\circ} \mathrm{C}$ and the interior of the kitchen is at $20{ }^{\circ} \mathrm{C}$, the equation that governs the testing presented in Figure 5 is indicated in Eq. (6) in function of water mass $\mathrm{m}$ and time $t$.

$$
T=20+(100-20) \exp \left(-\frac{5.7 E-06}{m} t\right)
$$

The times needed to cook typical foods with HRBC are indicated in Table 4. Both the time necessary for direct energy input and the time needed in $\mathrm{HRBC}$ are detailed. It is interesting to see that the HRBC cooking time is drastically reduced when the time avoided from boiling the pot on the stove is considered. The savings are between $50 \%$ and $90 \%$.

\subsection{Solar Oven Technology}

In arid and sunny climates, the solar oven is another potential energy-saving technology. This is a device 


\section{Pot temperature in heating retention box Mass variation in pot}

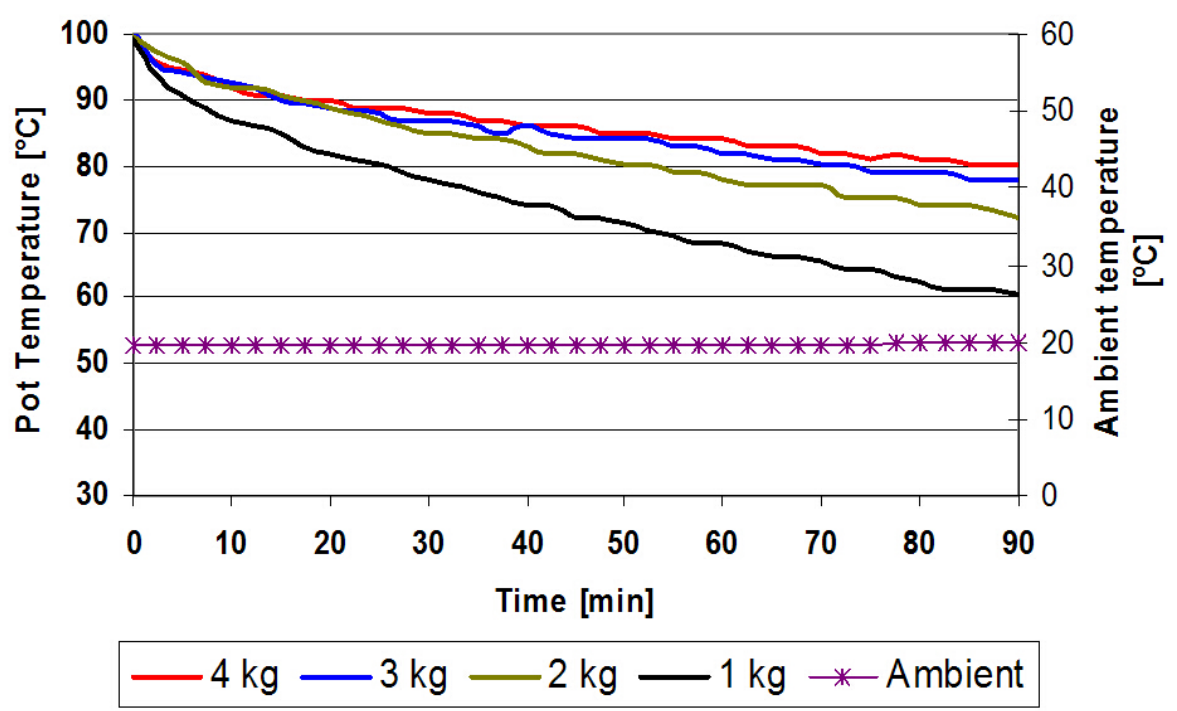

Figure 5. Pot temperature with heat retention box vs. charge of mass in pot

Table 4. Required time to cook $2.5 \mathrm{~kg}$ of food in a HRBC

\begin{tabular}{lrr}
\hline Foods & Minutes in boiling & Minutes in HRBC \\
\hline Stews in general & 7 & 60 \\
Hard vegetables: potatoes, carrots & 7 & 50 \\
Soft vegetables: green beans, chard, onion & 2 & 20 \\
Vegetable soup & 5 & 40 \\
Noodle soup & 2 & 25 \\
Vermicelli noodles & 2 & 30 \\
Polenta & 2 & 30 \\
Compotes & 5 & 25 \\
Legumes & 10 & 90 \\
Flank steak & 15 & 180 \\
Jams: different types & 15 & $180-240$ \\
\hline
\end{tabular}

that allows cooking using only solar energy on both clear (without clouds) and partially cloudy days. Solar ovens have their roots in the 18th century when a fuel shortage instigated their development. However, with the discovery and increasing use of oil-based energy, solar oven use diminished. It was not until the end of the 20th century that its use began to practically spread to people in rural areas, enabling lower consumption rates of firewood. Even still, it is not currently used in Latin America because of cultural barriers and the low price of fuels.

A solar oven consists of an insulated box with a window that permits solar energy to enter into the box. The temperature of the food that is held in the interior of box increases and allows food to reach the cooking temperature and then it is maintained until cooking is completed. The box may have 1 to 4 external reflectors

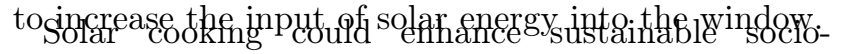
economic development and has the following advantages: since people do not have to look for firewood, they save time and effort, preserve their health and avoid the gradual destruction of their habitat. The participation of different family members in the solar cooking system clearly preserves the family union. All members can share different jobs involved in the solar cooking process.

The solar oven presented here is based in Derrick Hobbs solar oven called the "solar drum oven"(Hobbs 2003). Figure 6 shows a solar drum oven. This oven was replicated by Dr. Luis Saravia in Salta - Argentina (Saravia et al. 2003). Based on this idea, it was modified to be built in Mendoza, Argentina with local materials. The box is made from the recycling of a half barrel of petroleum or fossil fuel.

The box of the solar oven is half of a 44-gallon recycled drum. The window has two glass sheets with a hermetic chamber between them and with a wooden frame. The interior of the drum is coated with an aluminum sheet for ease of cleaning, and it has an absorber plate of steel painted black. Between the half drum 
and the interior aluminum coating, it has glass wool thermal insulation for energy conservation features. It is possible to rotate the cooker on its horizontal axis for optimal sun exposure at different solar altitudes. The solar oven has one exterior reflector made of wood with a coating of specular self-adhesive aluminized foil. The reflector protects the glass windows when the solar oven is not in use and keeps food warm when it is ready (Figure 6). This solar oven is placed on a table of appropriate height and has wheels to facilitate transportation and to be able to change its position in relation with the solar azimuth.

The solar furnace is used in the following way: the upper reflector is opened 30 to 45 minutes before putting in the food. The sun heats the absorber plate, whose temperature rapidly increases. Then, the food is placed inside the oven and remains there for the necessary cooking time. Table 5 indicates the approximate time required for complete cooking. During this time, every 30 or 40 minutes, it is necessary to move the oven in order to maintain the perpendicularity of the Sun's rays with the plane of the windowąŕs glass.

The basic method used for measuring the solar cookerąŕs performance is to expose the device, with $m \mathrm{~kg}$ of water in a pot, to solar radiation and measure the water temperature increase from initial temperature, $T_{o}$, to the boiling point, $T_{b}$. In addition, solar radiation on the cooker, ambient temperature and wind speed are also registered. The useful gain in energy is expressed in Eq. (7).

$$
Q_{u}=m \cdot c \cdot \Delta T
$$

where $Q_{u}$ is useful gain; $m$ is mass of water in the pot; $c$ is specific heat of water; $\Delta T$ is water temperature range in time $\Delta t$.

The instantaneous efficiency, $\eta$ is defined as the ratio of the useful gain over some specified time period to the incident solar energy over the same time period. This can be indicated by Eq. (8) (Duffie and Beckman 1991).

$$
\eta=\frac{Q_{u}}{A \int G_{T} d t}=\frac{m \cdot c\left(T_{2}-T_{1}\right)}{A \int G_{T} d t}
$$

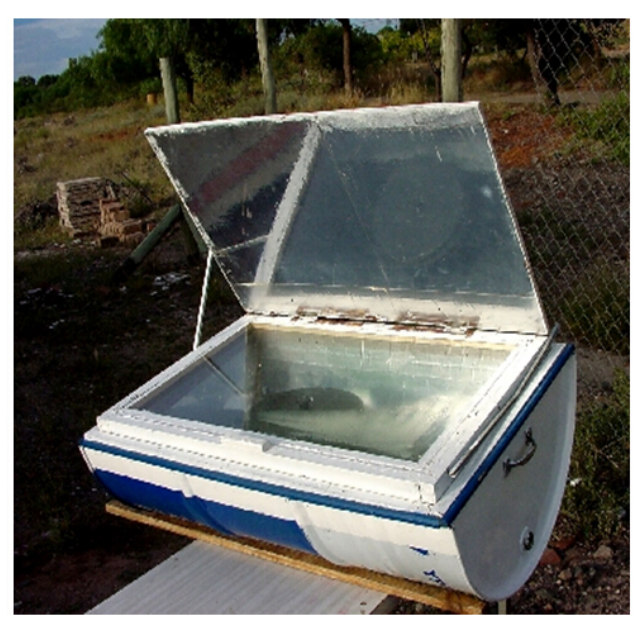

References:

1- Reflector.

2- Double glazed window with wooden frame.

3- Interior surface with aluminium sheet coating

4- Pot painted in black mate paint.

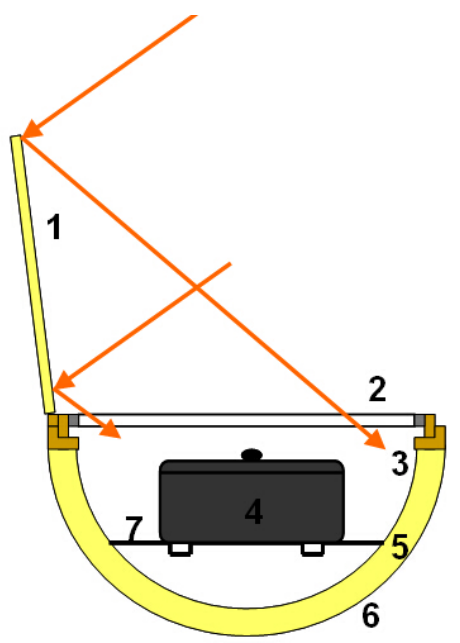

5- Glass wool thermal insulation

6- Exterior surface with painted steel sheet.

7- Solar absorber made with steel painted in black mate paint.

Figure 6. Solar drum oven for cooking made in Mendoza, Argentina with local materials

Table 5. Time of cooking with solar drum oven

\begin{tabular}{lr}
\hline Foods & Minutes for cooking \\
\hline Stews in general & 120 \\
Meat with vegetables & 120 \\
Fish with vegetables & 100 \\
Rice & 50 \\
Pizzas & 40 \\
Cakes & 100 \\
Bread & 180 \\
Jams, sweets & 240 \\
\hline
\end{tabular}


where $T_{2}$ is temperature of water at time $t_{2} ; T_{1}$ is temperature of water at time $t_{1} ; G_{T}$ is instantaneous solar radiation incident on the aperture area; and $A$ is collector surface aperture area.

Available solar energy is to be measured in the plane perpendicular to direct beam radiation (the maximum reading) using a radiation pyranometer.

This test determines the time required to reach 80 ${ }^{\circ} \mathrm{C}$ (20 minutes in Figure $7(\mathrm{a})$ ) and the time to reach boiling point (40 minutes in Figure $7(\mathrm{a})$ ). In order to calculate $Q_{u}$, interval temperature is taken from $40^{\circ} \mathrm{C}$ to boiling point minus $5^{\circ} \mathrm{C}$. The reason for this low temperature is to ensure that the contents of the pot are at a higher temperature than the ambient air. The higher temperature of interval is to discard values close to boiling point because the behavior is abnormal because of the partial evaporation of water (Funk 2000). The variables that are measured are water temperature, dry bulb ambient temperature, solar radiation and wind speed every 1 minute.

Instantaneous efficiency $\eta$ is calculated from Eq. (8) and drawn as a function of temperature differences water- ambient for each interval of time (Figure 7(b)). The efficiency result is indicated by Eq. (10).

$$
\eta=0.6199-0.0095\left(T_{w}-T_{a}\right)
$$

As can be observed, $\eta$ decreases as the temperature difference between the water and the air increases, that is when food temperature increases too. It is important to design a solar oven with a high initial $\eta$ and with good energy conservation characteristics.

The power of cooking for each interval is calculated as the useful gain to time interval. Then it must be corrected for the solar radiation standard of 700 $W / m^{2}$, multiplying the power observed by $700 \mathrm{~W} / \mathrm{m}^{2}$ and dividing by the average radiation registered during the corresponding interval. The reason is to help in the comparison of results from different locations and dates (Funk 2000). The power of cooking of the solar drum oven for $\mathrm{m}=2 \mathrm{~kg}$, is expressed in the Eq. (10):

$$
P_{c}=180.13-2.737\left(T_{w}-T_{a}\right)
$$

An interesting figure turns out to be the power standard of cooking $(W)$ to the difference of temperature of $50^{\circ} \mathrm{C}$ (Figure 7 ), as a simple measure of efficiency. The reason is that, a simple number facilitates more comparisons between different solar ovens. In this case, the cooking power is $43.28 \mathrm{~W}$ for $T_{w}-T_{a}=50^{\circ} \mathrm{C}$. This figure is similar to the one obtained for: a) the solar oven with tilt windows: $51 W$ (Esteves 2001); b) Nandwani solar Oven (Nandwani 2003): $58.23 \mathrm{~W}$; c) Nacuñán 1 solar oven: $61 W$ (Esteves et al. 2003).

\section{TECHNOLOGY TRANSFER}

HRBC and solar ovens have several advantages: a) they allow complete cooking almost in the same time as cooking in the gas kitchen; (b) they can be used to cook a variety of foods, including stews, noodles, bread, cakes, cakes of vegetables, and biscuits; (c) food does not stick in the pot, it does not burn, and it is not necessary to constantly check it during cooking.

Since 1994, INCIHUSA has been working on the technological adaption of solar cooking technology to local conditions (Esteves et al. 1999). A methodology for technology transfer has been adopted in order to spread solar cooking throughout isolated communities. The approach is based on the INTA- (National Institute of Food Technology of Chile) methodology (Guzman et al. 1992), in the belief that the transfer of solar cooker technology is rigorously associated with the development of the community.

Work has been done on technology transfer in isolated communities such as Nacuñan by the Department of Santa Rosa and La Salinilla, and by the Department

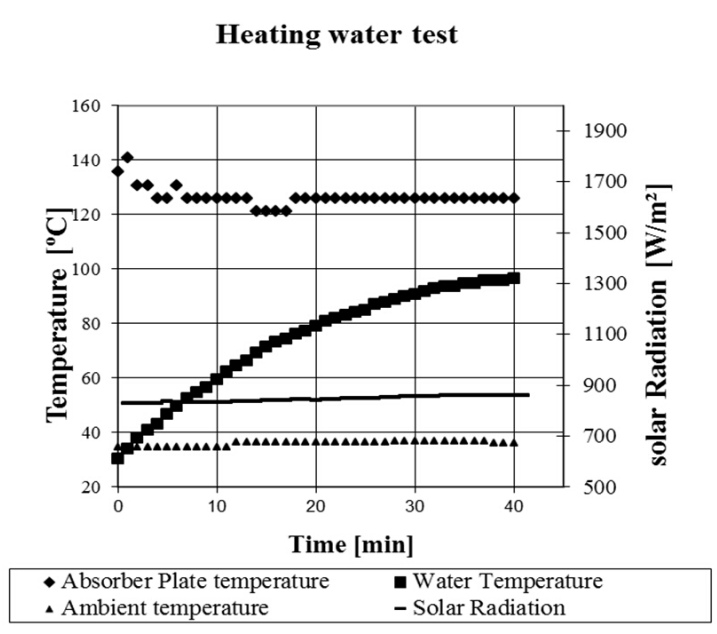

(a)

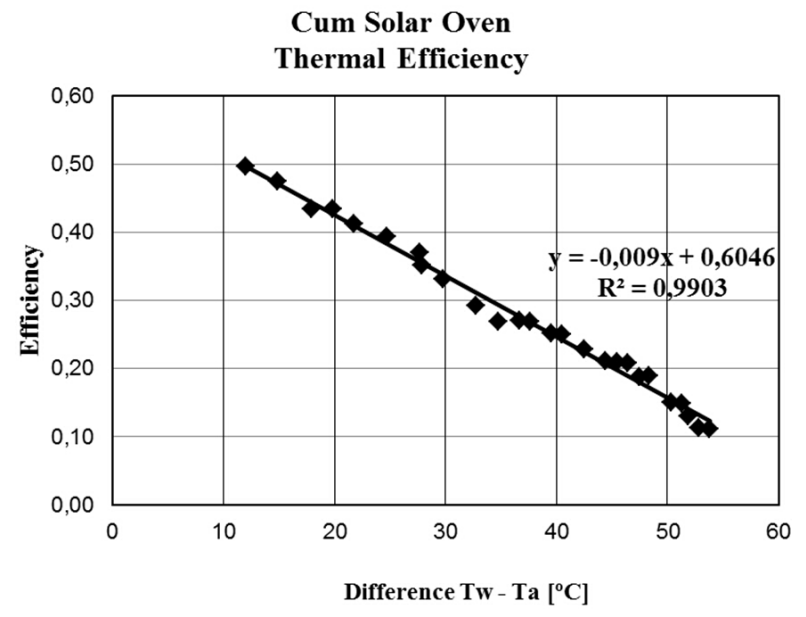

(b)

Figure 7. Heating water test and thermal efficiency of solar drum oven 
of Malargüe in Mendoza Province, in which technology transfer has been achieved through self-construction workshops as shown in Figure 8. In these cases, the research teams bring the know-how, the project provides the necessary materials, and the people of the community provide the labor. Using this process, local people become familiar with the technology, learning how to build the devices and how to cook with them. This approach gives a sense of ownership of the system in order to encourage its adoption more successfully.

\subsection{Energy Consumption after Adoption of Solar Cooking Technologies}

Taking into account the number of existing houses in the arid regions of Argentina (Table 1), along with the amount of sunny, partially sunny and cloudy days (Table 1), it is possible to calculate the amount of cooking energy saved by the use of energy-efficient equipment. It must be understood that only $50 \%$ of people from a community will adopt a new technology two or three years following its introduction, as indicated by Solar Box Cooker International experience with the extension of solar cookers, mainly in Africa. When more time has passed, the rest of the community will eventually adopt the new technology, although roughly $10 \%$ will not adopt it.

To calculate the fuel consumption, the amount of food prepared weekly has been found through a survey and the time required in the stove has been calculated by taking into account the calorific power and the performance of the burner of the stove (60\% in LPG Llobera 2000; $40 \%$ in FW Stein and Reynolds 1992).

Table 6 shows the energy consumption produced for the preparation of foods more frequently cooked in rural areas of Argentina.

In order to know the amount of energy saved, there are several models for the possible combinations of available energy resources: solar energy, energy conservation, FW and LPG. The optimal combinations were studied (Quiroga et al. 2010). This "optimal combination" means that on clear and partially cloudy days the solar ovens and the heat retention boxes combined with LPG, are used; on cloudy days, the heat retention boxes and LPG or FW are used. For this situation, the savings are $73 \%$ in LPG and $43 \%$ in $\mathrm{FW}$.

It is assumed that the Net Calorific Values for LPG are $50,298 \mathrm{~kJ} / \mathrm{kg}$ and $19,134.6 \mathrm{~kJ} / \mathrm{kg}$ for firewood $(20 \%$

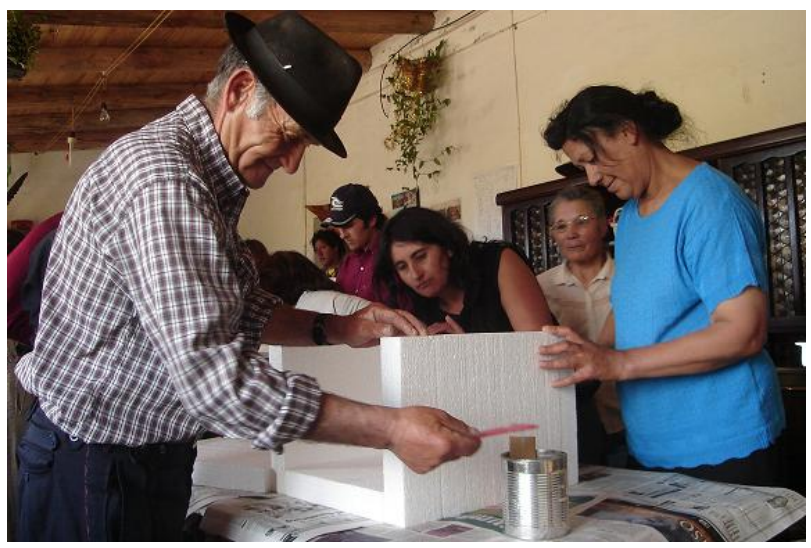

(a) Peoples in La Salinilla (1)

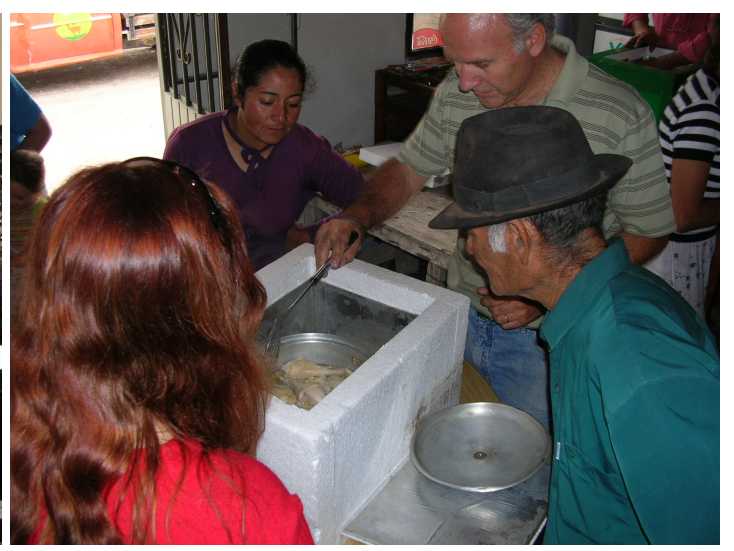

(b) Peoples in La Salinilla (2)

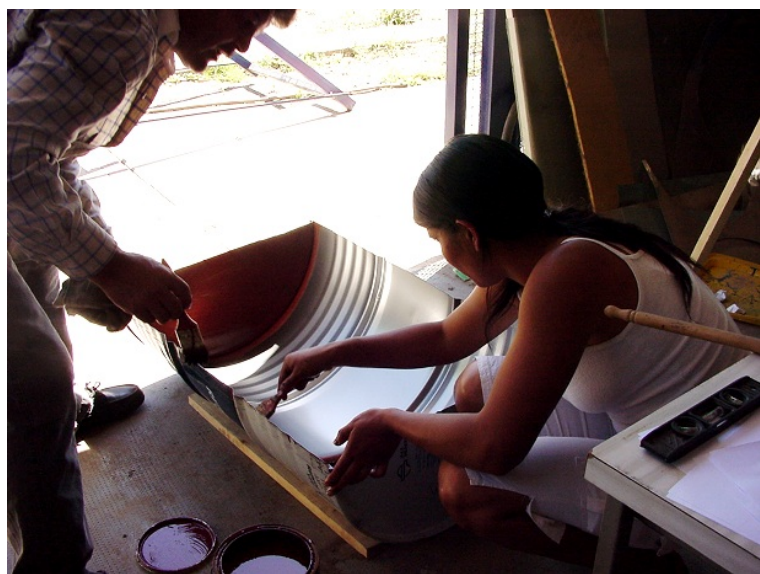

(c) Unemployed of Godoy Cruz Association (1)

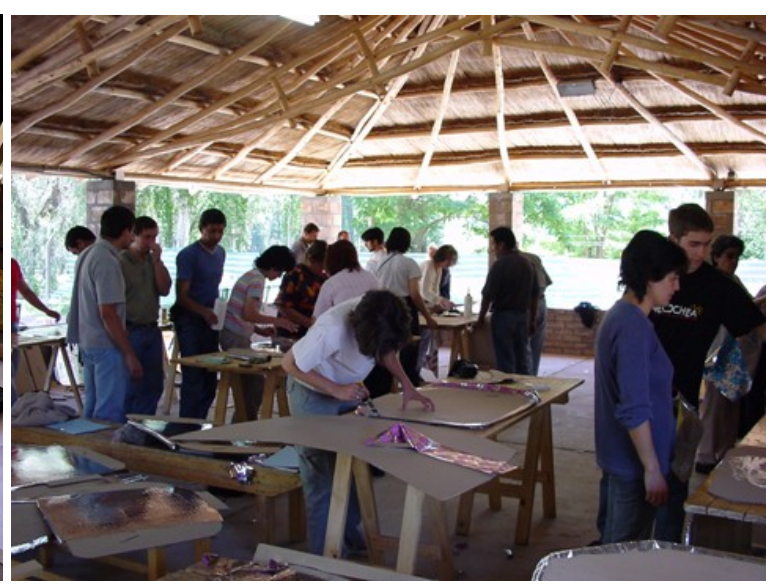

(d) Unemployed of Godoy Cruz Association (2)

Figure 8. Images of workshops that have been made in communities 
moisture content). The FW considered is Prosopis flexuosa (carob) an abundant tree in arid zones of Argentina.

From these measures, Table 7 indicates the energy savings in cooking by solar oven and HRBC use. This is calculated as a function of clear, partially clear and cloudy days of each zone. Table 8 presents total savings in LPG and FW.

It is possible to observe that the level of savings is around $65 \%$ of the total energy spent annually in cooking.

\subsection{Environment Impact of Technology Use}

The impact caused to the environment is calculated by taking into account emission factors linked to the amount of gases emitted by each type of energy consumed. These emissions are directly proportional to energy consumption, and are the main greenhouse emissions. The general equation for the estimation of emissions is indicated in Eq. (11).

$$
E=A \cdot F
$$

where $E$ is total annual emission of pollutants; $A$ is annual $\mathrm{kg}$ of fuel saved; and $F$ is emission factor (pollutants mass emitted per $\mathrm{kg}$ of fuel saved.

The GHG emissions of carbon dioxide $\left(\mathrm{CO}_{2}\right)$ are indicated in Table 9 . In this case, the emission factors indicated by the Bariloche Foundation (2007) are used for reference. Total savings in emissions by the use of the presented technologies are estimated to be 540.0 $\mathrm{tCO}_{2} / \mathrm{yr}$. It must be noted that the value for LPG does not account for indirect emissions associated with extraction, refining, etc.

Tables 9 indicates that GHG emissions from cooking, represented here by $\mathrm{CO}_{2}$, could be decreased by $65.7 \%$ in LPG and $63.8 \%$ in FW if the HRBC and Solar Oven technologies in arid zones of Argentina are incorporated, assuming that $50 \%$ of the population adopts the technology. In addition, when burning firewood, carbon dioxide and particulate matter are produced. When LPG is used, carbon dioxide, sulphur dioxide, methane particles and other pollutants are produced. It is important to note that carbon dioxide was in the atmosphere many centuries ago, when the environment was entirely different (not biogenic $\mathrm{CO}_{2}$ ) (Suarez 1993). Therefore burning LPG has a greater impact that burning FW.

Table 6. Energy consumption of LPG and FW in cooking

\begin{tabular}{llrrr}
\hline $\begin{array}{l}\text { Geographical } \\
\text { zone }\end{array}$ & $\begin{array}{l}\text { Houses } \\
\left(\mathrm{n}^{\circ} \text { of unit) }\right.\end{array}$ & \multicolumn{2}{c}{ Energy comsumption } & $\begin{array}{r}\text { Total } \\
\text { LPG }(\mathrm{MJ} / \mathrm{yr})\end{array}$ \\
\hline Northwestern & 49,871 & $304,013.6$ & $1,145,038.2$ & $1,449,051.8$ \\
Northeastern & 34,814 & $212,226.1$ & $799,329.4$ & $1,011,555.6$ \\
Centralwestern & 95,109 & $579,784.5$ & $2,183,702.6$ & $2,763,487.1$ \\
Patagonian North & 32,319 & $197,016.6$ & $742,044.2$ & $939,060.9$ \\
Patagonian South & 20,621 & $125,705.6$ & $473,458.2$ & $599,163.8$ \\
Total & 232,734 & $1,418,746.4$ & $5,343,572.6$ & $6,762,319.1$ \\
\hline
\end{tabular}

Table 7. Energy saving in cooking by solar oven and HRBC use in function of cloudy cover of the days

\begin{tabular}{lrrrrrrr}
\hline $\begin{array}{l}\text { Geographical } \\
\text { zone }\end{array}$ & $\begin{array}{r}\text { Clear } \\
\text { days }\end{array}$ & $\begin{array}{r}\text { Saving LPG } \\
(100 \%)\end{array}$ & $\begin{array}{r}\text { Saving FW } \\
100 \%\end{array}$ & $\begin{array}{r}\text { Partially } \\
\text { clear days }\end{array}$ & $\begin{array}{r}\text { Cloudy } \\
\text { days }\end{array}$ & $\begin{array}{r}\text { Saving LPG } \\
(\mathrm{MJ} / \mathrm{yr})^{*}\end{array}$ & $\begin{array}{r}\text { Saving FW } \\
(\mathrm{MJ} / \mathrm{yr})^{*}\end{array}$ \\
\hline Northwestern & 143.9 & $59,928.2$ & $451,427.4$ & 142.8 & 78.3 & $134,434.8$ & $325,997.1$ \\
Northeastern & 120.1 & $34,915.6$ & $263,012.2$ & 142.0 & 102.9 & $103,948.4$ & $252,069.1$ \\
Centralwestern & 128.2 & $101,819.7$ & $766,988.2$ & 179.7 & 57.1 & $274,585.9$ & $665,855.8$ \\
Patagonian North & 110.0 & $29,687.4$ & $223,629.8$ & 187.2 & 67.8 & $100,478.5$ & $243,654.8$ \\
Patagonian South & 77.6 & $13,362.7$ & $100,658.5$ & 215.6 & 71.8 & $72,255.6$ & $175,215.8$ \\
\hline
\end{tabular}

Note: * - $73 \%$ in LG; $43 \%$ in FW (Quiroga et al. 2010)

Table 8. Total energy saving of FW and LPG by solar oven and HRBC use

\begin{tabular}{lrrrrr}
\hline \multirow{2}{*}{$\begin{array}{l}\text { Geographical } \\
\text { zone }\end{array}$} & \multicolumn{2}{c}{ Annual savings of LPG } & \multicolumn{2}{c}{ Annual savings of FW } & Total \\
\cline { 2 - 6 } & $(\mathrm{MJ} / \mathrm{yr})$ & $\%$ & $(\mathrm{MJ} / \mathrm{yr})$ & $\%$ & $(\mathrm{MJ} / \mathrm{yr})$ \\
\hline Northwestern & $194,363.0$ & 63.9 & $777,424.4$ & 67.9 & $971,787.4$ \\
Northeastern & $138,863.9$ & 65.4 & $515,081.3$ & 64.4 & $653,945.2$ \\
Centralwestern & $376,405.6$ & 64.9 & $1,432,844.0$ & 65.6 & $1,809,249.6$ \\
Patagonian North & $130,165.9$ & 66.1 & $467,284.6$ & 63.0 & $597,450.5$ \\
Patagonian South & $85,618.3$ & 68.1 & $275,874.3$ & 58.3 & $361,492.6$ \\
Total & $925,416.7$ & 65.7 & $3,468,508.6$ & 63.8 & $4,393,925.3$ \\
\hline
\end{tabular}


Table 9. Emission savings of $\mathrm{CO}_{2}$ from $\mathrm{HRBC}$ and the solar oven use in the arid zone of Argentina

\begin{tabular}{lrr}
\hline Geographical & $\mathrm{LPG}$ & $\mathrm{FW}$ \\
\cline { 2 - 3 } Zone & $\mathrm{kgCO}_{2} / \mathrm{yr}$ & $\mathrm{kgCO}_{2} / \mathrm{yr}$ \\
\hline Northwestern & $12,257.90$ & $106,540.00$ \\
Northeastern & $8,757.70$ & $71,694.00$ \\
Centralwestern & $23,738.80$ & $198,353.50$ \\
Patagonian North & $8,209.20$ & $65,500.30$ \\
Patagonian South & $5,399.70$ & $39,631.50$ \\
\hline
\end{tabular}

When trees are burned one of their most important functions is lost, which is to clean the atmosphere by absorbing the carbon dioxide (Nandwani 2003) and in arid zones, the desertification process is possible.

\section{CONCLUSIONS}

This paper demonstrates that the adoption of energyefficient cooking technologies, such as the HRBC and the solar oven, in arid zones of Argentina could generate:

1. Energy savings of $65.7 \%$ in LPG and $63.8 \%$ in FW, when climatic conditions and the number of houses in each zone are taken into account. This produces economical savings by reducing the number of LPG bottles purchased.

2. Decrease in environmental impact by around $540.0 \mathrm{tCO}_{2} / \mathrm{yr}$.

3. Better quality of life for the user by producing substantial savings in time spent collecting FW.

To achieve these results transfer of the new technologies should be accompanied by fundamental actions:

1. Development of regulatory frameworks that promote energy efficiency measures;

2. Educational programs on energy-efficient cooking taught in rural schools;

3. Awareness, dissemination and education of consumers and the general public;

4. Stimulation of the market through economic incentives and disincentives;

5. Appropriate mechanisms such as: soft rate credit or tax incentives, to finance the acquisition of the necessary materials to build the device or to buy it;

6. Promotion of research and development in energy conservation and clean energy use (R \& D);

7. Dissemination of knowledge on available technologies, costs and benefits of energy efficiency and solar use.

\section{REFERENCES}

Bariloche Foundation (2007). $2^{\circ}$ Comunicación Nacional de la República Argentina a la Convención
Marco de las Naciones Unidas para el Cambio Climático. Marcelo Kohan Press, Buenos Aires, Argentina.

Cerioni, L. and Morresi, S. (2008). "Política energética argentina: análisis de la legislación vigente tendiente a promocionar el uso de energías renovables." Avances en energías renovables y medio ambiente, $12(7), 73-78$.

Duffie, J. A. and Beckman, W. A. (1991). Solar Engineering of Thermal Process. John Wiley \& Sons. New York, United States.

Esteves, A. (2001). "Ensayo de potencia para medir el Comportamiento Térmico de Hornos Solares: Su validez en funión de la época del año." Avances en energías renovables y medio ambiente, 5(2), 49-54.

Esteves, A., Buenanueva, F., and Cavagnaro, L. (2006). "Pasteurizacion de leche utilizando un horno solar." Avances en energías renovables y medio ambiente, 10(3), 29-34.

Esteves, A., Fink, P. A., Nandwani, S., Fonseca, S., and Collares, P. M. (2003). Las cocinas solares en Iberoamerica. Salta, Argentina, Chapter Estudio de casos.

Esteves, A., Pattini, A., Mesa, A., Candia, R., and Delugan, M. (1999). Ecosystems and Sustainable Development II. WIT press, United Kingdom, Chapter Sustainable development of isolated communities and the role of solar technology: The case of Nacuñan, Santa Rosa, Mendoza, Argentina, 235244.

Filipin, C., Beascochea, A., Esteves, A., de Rosa, C., Cortegoso, J. L., and Esterlich, D. (1998). "A passive solar building for ecological research in Argentina: The first two years experience." Solar Energy, $63,105-115$.

Funk, P. A. (2000). "Evaluating the international standard procedure for testing solar cookers and reporting performance." Solar Energy, 68(1), 1-7.

Ganem, C. (2006). Rehabilitación ambiental de la envolvente de viviendas: El caso de Mendoza. $\mathrm{PhD}$ Thesis, ETSA Barcelona - UPC - Cataluña, España.

Guzman, M. T., Jury, G., and Durán, E. (1992). Evaluation INTA-TECA Solar Cooking Program and Pilot Project in Villaseca, IV Region. Nutrition and Food Technology Institute, University of Chile, Santiago, Chile.

Hobbs, D. (2003). Drum Solar Oven. Solar Cooking. 
Avaliable at <http://solarcooking.org $>$ (accessed $16 / 03 / 2013)$.

INDEC (2012). Censo de Población y vivienda 2010. INDEC, Ministerio de Economía, Gobierno de la Republica Argentina, Buenos Aires, Argentina.

IPCC (2011). Special Report on Renewable Energy Sources and Climate Change Mitigation. Working group III of IPCC, Cambridge University Press, Cambridge, United Kingdom.

Kreith, F., a. B. M. (2001). Principios de transferencia de calor. Thompson learning Press, Mexico.

Llobera, R. (2000). Tratado general de gas. Cesarini Hnos Press, Buenos Aires, Argentina.

Mandil, C. (2007). Reference Scenario: World Primary Energy Demand. Internacional Energy Agency. Available at <http://www.ifp.fr/content/> (accessed 20/03/2013).

Mercado, M. V. and Esteves, A. (2004). "Tecnologías para la conservación de energía en cocción de alimentos: Caja térmica para comedores comunitarios y/o escuelas rurales." Avances en energías renovables y medio ambiente, 8(7), 55-60.

Mercado, M. V., Esteves, A., Filippín, M. C., and Flores, L. S. (2013). "Passive solar radiant system, sirasol. physical-mathematical modeling and sensitivity analysis." Solar Energy, 96, 10-20.

Ministerio de Economía (2012). Balance Energético. Ministerio de Economía. Gobierno de la Nación Argentina. Available at <http://www.mecon.gov.ar $>$ (accessed 02/03/2013).

Mitchell, J. and Esteves, A. (2004). "Diagnóstico de consumos energéticos de un asentamiento rural del oasis norte de mendoza." Avances en energías renovables y medio ambiente, 8(7), 43-48.

Nandwani, S. (2003). Las cocinas solares en Iberoamerica. Salta, Argentina, Chapter Soluciones técnicas.

Quiroga, V. N., Martínez, C., and Esteves, A. (2010). "Modelo de manejo energético en base a tecnología solar y biomasa para cocción sustentable en comunidades de zonas desérticas y semidesérticas." Energías Renovables y Medio Ambiente, 26, 9-18.

Saravia, L., Caso, R., and Fernández, C. (2003). "Cocina solar de construcciloón sencilla." Avances en Energías Renovables y Medio Ambiente, 7(3), 13-17.

Secretaría de Ambiente y Desarrollo Sustentable (2012). Manual sobre Desertificación. Avaliable at $<$ http://www.ambiente.gov.ar/archivos/web/> (accessed on 15/03/2013).

SMN (2004). Estadísticas climatológicas de la Republica Argentina 1990-2000. Servicio Meteorológico Nacional, Secretaría de Planeamiento, República Argentina.

Stein, B. and Reynolds, J. (1992). Mechanical and Electrical Equipment for Building. Wiley, New York, United State.

Suarez, C. (1993). Impactos ambientales del sistema energético de América Latina, 1970-1990/19902010. OLADE, Fundación Bariloche Press, Bariloche, Argentina.

Volantino, V. and Cornejo, J. (2005). Ahorro y certificación energética: la envolvente de los edificios. Saber Como, Buenos Aires, Argentina. 